\title{
Assessment of the Degree Ageing Labour Force for Example of Poland and Slovakia
}

\author{
Andrzej Skibiński ${ }^{1}$
}

\begin{abstract}
The process of population ageing is increasing on an unprecedented scale, affecting European populations and other highly developed countries worldwide. By looking at this process from a demographic perspective, it is possible to assess both the severity of this phenomenon and its dynamics at a specific time and in a specific area such as an administrative unit, country or region. The aim of this publication is to present the dynamics of the process of population ageing using Poland and Slovakia as examples, as well as selected findings of a questionnaire survey showing respondents' opinions about problems connected with ageing and shrinking of potential labour force. The paper is a next stage of the research into changes in population age structures and their consequences in European Union countries. This time, attention was focused on the dynamics of changes in the share of working age population. The dynamics of the population ageing process was determined in this case using demographic ageing index (Polish: WSD) based on point differences between younger and older population shares.
\end{abstract}

Keywords: ageing of population, labour force, demographic ageing index

\section{Introduction}

When examining the process of population ageing in the context of research, it is important to note that research into this process was undertaken relatively early, but with respect to an individual. It first became a subject of interest in natural sciences such as medicine and biology, and then was recognised in social sciences, e.g. sociology. With later emergence of studies on the process of human population ageing, a discipline dealing with these issues was distinguished, and the phenomenon started to be examined at an aggregated level, on a region, country and continent scale. Population ageing is a demographic process of which the public has been most acutely aware in recent years. Visible changes in the population age structure are causing an increase in the number and share of older age groups, and a decrease in the share and number of younger age groups. This is a phenomenon that entails a range of socio-economic consequences. In recent years, this process has also affected working age people, resulting in an increased focus on pre-retirement people. Also in this case, the public, especially employers, is increasingly aware of occurring changes. In view of the above, the aim of this publication is to present the dynamics of the process of population ageing using Poland and Slovakia as examples, as well as selected findings of a questionnaire survey showing respondents' opinions about problems connected with ageing and shrinking of potential labour force. The paper is a next stage of the research into changes in population age structures and their consequences in European Union countries. This time, attention was focused on 
the dynamics of changes in the share of working age population.

\section{Methodological Information}

Modern trends in demographic processes have an important impact on changes in the labour market. For the purpose of this paper, appropriate quantitative and qualitative analyses were conducted using existing data from Eurostat data base. The dynamics of the population ageing process was determined in this case using demographic ageing index (Polish: WSD) based on point differences between younger and older population shares (Długosz, 1998):

$\mathrm{WSD}=[\mathrm{U}(0-14) \mathrm{t}-\mathrm{U}(0-14) \mathrm{t}+\mathrm{n}]+[\mathrm{U}(\geq 65) \mathrm{t}+\mathrm{n}-\mathrm{U}(\geq 65) \mathrm{t}]$,

where:

$\mathrm{U}(0-14) \mathrm{t}$ - share of people aged $0-14$ at the beginning of the research period,

$\mathrm{U}(0-14) \mathrm{t}+\mathrm{n}-$ share of people aged $0-14$ at the end of the research period,

$\mathrm{U}(\geq 65) \mathrm{t}$ - share of people aged 65 and over at the beginning of the research period, $\mathrm{U}(\geq 65) \mathrm{t}+\mathrm{n}-$ share of people aged 65 and over at the end of the research period.

In order to show the population ageing process in terms of economic age groups, economic ageing index (Polish: WSE) was used, which is based on point changes in economic age groups (Kurek, 2008):

\section{$\mathrm{WSE}=[\mathbf{P}(\mathrm{m}) \mathrm{t}-\mathbf{P}(\mathrm{m}) \mathrm{t}+\mathrm{n}]+[\mathbf{P}(\mathrm{pm}) \mathrm{t}-\mathbf{P}(\mathrm{pm}) \mathrm{t}+\mathrm{n}]+[\mathbf{P}(\mathrm{ps}) \mathrm{t}+\mathrm{n}-\mathbf{P}(\mathrm{ps}) \mathrm{t}]+$ $[\mathbf{P}(\mathrm{s}) \mathrm{t}+\mathbf{n}-\mathbf{P}(\mathrm{s}) \mathrm{t}]$,

where:

$\mathrm{P}(\mathrm{m})$ - share of pre-working age people at the beginning $(\mathrm{t})$ and at the end $(\mathrm{t}+\mathrm{n})$ of the research period,

$\mathrm{P}(\mathrm{pm})$ - share of mobile working age people at the beginning $(\mathrm{t})$ and at the end $(\mathrm{t}+\mathrm{n})$ of the research period,

$\mathrm{P}(\mathrm{ps})$ - share of non-mobile working age people at the beginning $(\mathrm{t})$ and at the end $(\mathrm{t}+\mathrm{n})$ of the research period,

$\mathrm{P}(\mathrm{s})$ - share of post-working age people at the beginning $(\mathrm{t})$ and at the end $(\mathrm{t}+\mathrm{n})$ of the research period.

Additionally, the paper presents selected results of a questionnaire survey addressing, among other things, the research population's perception of the problems connected with the ageing and shrinking of potential labour force. The survey was conducted among a population of university students $(\mathrm{N}=254)$ of part-time studies of the first and second degree in Poland and Slovakia in the period from March to April 2017. The method used was non-probabilistic sampling based on a diagnostic survey ${ }^{1}$ conducted on respondents gathered at one place and time. The research was empirical in nature, and the resulting findings refer to the surveyed population only and are not representative. They may however fill the gap in regional studies on migration processes. Below are selected characteristics of the research sample.

1 The diagnostic survey method is a way of gathering knowledge about the structural and functional phenomena and dynamics of social phenomena, opinions and views of selected communities. 
Table 1. Selected characteristics of the surveyed population

\begin{tabular}{|c|c|c|c|c|}
\hline Feature & \multicolumn{4}{|c|}{ in $[\%]$} \\
\hline \multirow{2}{*}{ Sex } & \multirow{2}{*}{\multicolumn{2}{|c|}{$\begin{array}{c}\text { female } \\
76.9\end{array}$}} & \multicolumn{2}{|c|}{ male } \\
\hline & & & & \\
\hline \multirow{2}{*}{ age group } & $<25$ & $26-34$ & $35-39$ & $40-44$ \\
\hline & 76.4 & 15.7 & 5.8 & 2.1 \\
\hline \multirow{2}{*}{ Type of job } & \multicolumn{2}{|c|}{ blue-collar } & \multicolumn{2}{|c|}{ white-collar } \\
\hline & \multicolumn{2}{|c|}{51.8} & \multicolumn{2}{|c|}{48.2} \\
\hline \multirow{2}{*}{ years worked } & up to 1 & $1-5$ & $6-10$ & $10>$ \\
\hline & 35.2 & 51.3 & 8.6 & 4.9 \\
\hline
\end{tabular}

Source: own work based on survey

\section{Theoretical Background}

The process of population ageing is increasing on an unprecedented scale, affecting European populations and other highly developed countries worldwide. By looking at this process from a demographic perspective, it is possible to assess both the severity of this phenomenon and its dynamics at a specific time and in a specific area such as an administrative unit, country or region. A study like this has an autonomous informative value in itself, as well as providing a necessary knowledge resource for formulating non-demographic assessments and consequences of the phenomenon in question (Kowaleski and Szukalski, 2008). The research problem defined by the subject of this work is examined mainly from the economic perspective. Throughout the history of two hundred years, there were two different periods in terms of the number of labour force. The first period saw an increase in the labour force, which, fully used, became the main factor in the socio-economic growth. The second period saw a decrease in the labour force as a result of a decrease in the birth rate and increase in the number of people entering retirement age. Europe is in the phase of labour force shrinking, and there are only few countries where this process is not growing so dynamically. Labour force shrinking is a consequence of population ageing, which is very burdensome for the economy. Its effects may prove very serious, not only for the economic growth in many countries, but also for the chances of sustainable development (Golinowska, 2008). Directs factors that impact population ageing include future and current trends in fertility, mortality and migration. Furthermore, population ageing may be a consequence of a slowdown of the increase in the number of young people and acceleration of the increase in the number of older people, or both these factors at the same time. Thus, the causes of the ageing and shrinking of potential labour force should be sought in demographic theories, because according to numerous researchers (Frątczak, 2016; Kirk, 2016; McDonald, 2013; Matthews and Parker, 2013; Lee and Reher, 2011), population ageing is a result of demographic transition, when fertility and mortality decline, which is characteristic of phase 4 of the demographic transition. However, the authors of the concept of the second demographic transition (Van de Kaa, 1987; Sobotka, 2008; Caldwell, 2006) see the causes of population ageing in fertility rate declining below the replacement level (TFR <2.1) as a result of changes in social, lifestyle and cultural norms, such as postponing procreation plans, pursuing professional career, getting married at a later age or 
an increase in divorces. A sharp decrease in fertility rate in Central and Eastern European countries occurred in the early 1990s, and was connected, among other things, with processes of social, economic and political transformations which took place e.g. in Poland and Slovakia (Bijak et al., 2013; Skibiński, 2017) Thus, a direct consequence of the process of population ageing in a given area is increased pressure on working age population to support increasing population above working age, which means insufficient labour supply. It is expected that entrepreneurs will need to find appropriate mechanisms to ensure better management of labour force, especially people in older age groups. Some solutions to these challenges will be presented further in the paper.

\section{Result of Research}

The process of population ageing, as was indicated above, is a widespread process in the modern world. It was caused by declining fertility rate and declining mortality rate that led to longer average life expectancy. Data contained in Table 1 is the base-line data in analysis of the dynamics of changes in the population age structure, which can be examined in two aspects. First, as change in the population age structure between two selected periods of time, and second, as continuous changes, e.g. annual. Thus, the bigger the dynamics of the process, the bigger the increase in the share of older population and the bigger the decrease in the share of young population. 2004 (i.e. the year of Poland's and Slovakia's accession to the European Union) was accepted as the starting point for comparisons. To determine future trends in the dynamics of changes in the number and structure of population, Eurostat's latest demographic forecast by 2080 was used.

Table 2. Change in the total population by economic age groups, and in migration rates in Poland and Slovakia in the $2004-2050$ period.

\begin{tabular}{|c|c|c|c|c|c|c|c|c|}
\hline \multirow{5}{*}{ Years } & \multicolumn{8}{|c|}{ Population } \\
\hline & \multirow{3}{*}{$\begin{array}{c}\text { total } \\
{[\text { in 1000] }}\end{array}$} & \multirow{3}{*}{$\begin{array}{c}\text { dynamics } \\
\text { indicator } \\
{[2004-100]}\end{array}$} & \multirow{3}{*}{$\begin{array}{c}\text { net } \\
\text { migration }\end{array}$} & \multicolumn{5}{|c|}{$\begin{array}{l}\text { Population share by economic age groups } \\
{[\text { in } \%]}\end{array}$} \\
\hline & & & & 014 & & 64 -to & & $65+$ \\
\hline & & & & $0-14$ & $15-44$ & & $45-64$ & OJT \\
\hline & \multicolumn{8}{|c|}{ Poland } \\
\hline 2004 & 38190.608 & 100.0 & -9382 & 17.2 & 44.6 & 69.8 & 25.2 & 13.0 \\
\hline 2010 & 38022.869 & 99.6 & $+5,027$ & 15.3 & 43.5 & 71.1 & 27.6 & 13.6 \\
\hline 2017 & 37972.964 & 99.4 & $+11,507$ & 15.1 & 41.8 & 68.4 & 26.6 & 16.5 \\
\hline $2020 * *$ & 37930.818 & 99.3 & -33 & 15.3 & 40.2 & 66.3 & 26.1 & 18.4 \\
\hline \multirow[t]{2}{*}{$2050 *$} & 34372.849 & 90.0 & $+29,737$ & 13.2 & 31.0 & 56.1 & 25.1 & 30.6 \\
\hline & \multicolumn{8}{|c|}{ Slovakia } \\
\hline 2004 & 5371.875 & 100.0 & -1085 & 17.6 & 38.4 & 70.8 & 32.4 & 11.6 \\
\hline 2010 & 5390.410 & 100.3 & $-4,929$ & 15.5 & 38.7 & 72.1 & 33.4 & 12.4 \\
\hline 2017 & 5435.343 & 101.2 & $+3,885$ & 15.5 & 37.7 & 69.5 & 31.8 & 15.0 \\
\hline 2020* & 5458.718 & 101.6 & $+5,919$ & 15.5 & 42.4 & 67.9 & 25.5 & 16.6 \\
\hline $2050 *$ & 5261.609 & 97.9 & $+6,466$ & 14.0 & 31.9 & 57.0 & 25.1 & 29.0 \\
\hline
\end{tabular}

*prognostic data

Source: own work based on: Eurostat data base (access: 9.04.2018) 
Data contained in Table 2 shows a clear decline in total population for Poland. The situation looks quite differently for Slovakia, where the period between 2004 and 2017 saw a slight increase in the total population. The change in the dynamics is a result of the contribution of not only the increasing natural mobility of population, but also of net migration, especially external one, which played a significant role in the case of Poland. According to prognostic data, both Poland and Slovakia should expect a downward trend in the total population. These trends are in line with the trends in the other EU's states, but the dynamics varies a little. From the perspective of potential labour fore, it is important to present changes in population structure by economic age groups. In Poland and Slovakia, the share of people aged 0-14 is visibly declining, while the share of those aged $65+$ is growing. This, in turn, results in a decline in the share of working age population. Given the prognostic data, we should expect the above trends in Poland and Slovakia to continue, which results and will result in an increasing process of population ageing in these countries. However, indicating only the total working age population does not provide the full picture of the changes taking place in this group of population. It is also important to show changes in the number of people in the mobile age group, i.e. 15-44, and those in non-mobile age group, i.e. 45-64. The data shows a clear decrease in the share of population in the mobile age group, resulting in a high share of population in the non-mobile age group in the overall working age population, both in Poland and Slovakia. Given the above, an attempt was made to assess the changes in the population age structure by determining the number of non-working age population relative to working age population.

Table 3. Economic dependency ratio in Poland and Slovakia

\begin{tabular}{|c|c|c|c|}
\hline \multirow{3}{*}{ Years } & $\begin{array}{c}\text { Economic dependency ratio } \\
\text { EDR0 }=\frac{L_{0-14}+L_{65+}}{L_{15-64}} \times 1000\end{array}$ & $\begin{array}{c}\text { Child dependency ratio } \\
\text { EDR1 }=\frac{L_{0-14}}{L_{15-64}} \times 1000\end{array}$ & $\begin{array}{c}\text { Aged dependency ratio } \\
\text { EDR2 }=\frac{L_{65+}}{L_{15-64}} \times 1000\end{array}$ \\
\cline { 2 - 4 } & \multicolumn{3}{|c|}{$\begin{array}{c}\text { per 1000 working age people } \\
\text { Poland }\end{array}$} \\
\hline $\mathbf{2 0 0 4}$ & 433 & 246 & 186 \\
\hline $\mathbf{2 0 1 0}$ & 406 & 215 & 191 \\
\hline $\mathbf{2 0 1 7}$ & 463 & 220 & 242 \\
\hline $\mathbf{2 0 2 0} * *$ & 508 & 231 & 277 \\
\hline $\mathbf{2 0 5 0} * *$ & 781 & 235 & 545 \\
\hline & & per 1000 working age people \\
Slovakia & \\
\hline $\mathbf{2 0 0 4}$ & 411 & 248 & 163 \\
\hline $\mathbf{2 0 1 0}$ & 387 & 215 & 215 \\
\hline $\mathbf{2 0 1 7}$ & 437 & 222 & 244 \\
\hline $\mathbf{2 0 2 0} * *$ & 472 & 228 & 509 \\
\hline $\mathbf{2 0 5 *}$ & 548 & 245 & \\
\hline
\end{tabular}

*prognostic data

Source: as in table 2

Analysis of economic dependency ratios shows that the total dependency ratios (EDR0) for Poland and Slovakia between 2004 and 2010 ranged respectively from 433 to 406 and 
from 411 to 387 non-working age people per 1000 working age people. Taking into account prognostic data, it can be concluded that after 2010 the dependency ratio will systematically increase to exceed 500 (for 2050) both in Poland and Slovakia, but with slightly different dynamics. In the case of Poland, the above-presented data shows higher ratio of economically active population to non-active population as a result of a faster population ageing process. It should be noted that the child dependency ratio is determined by the rate of live births and the shares of pre-working age and post-working age people in the population age structure, among other things. The 2004-2010 period saw a clear decline in EDR1 in Poland (from 246 to 215) and Slovakia (from 248 to 215). However, in the 2010-2017 and 2020-2050 periods, there is a reverse trend. The countries analysed recorded a slight increase in EDR1 due to an increase in birth rate in this period. The growing rise in aged dependency ratio (EDR2) represents a significant challenge not only for a country's socio-economic policy, but above all in the SME sector. Over the whole analysis period, i.e. from 2004 to 2015, there was a clear increase in EDR2 (from 186 to 545 and from 163 to 509 for Poland and Slovakia respectively). In Poland, this process will increase much faster than in Slovakia. For a more comprehensive assessment, demographic ageing index and economic ageing index were took into account in the dynamics of the population ageing process (Table 4).

Table 4. Dynamics of the population ageing processes in Poland and Slovakia

\begin{tabular}{|c|c|c|}
\hline \multirow[t]{2}{*}{ Years } & $\begin{array}{c}\text { Demographic ageing index } \\
\text { WSD }\end{array}$ & $\begin{array}{c}\text { Economic ageing index } \\
\text { WSE }\end{array}$ \\
\hline & \multicolumn{2}{|c|}{$\begin{array}{ll}\text { Poland } \\
\end{array}$} \\
\hline 2004 & - & - \\
\hline 2010 & +2.5 & +6.0 \\
\hline 2017 & +3.1 & +3.8 \\
\hline $2020 * *$ & +1.7 & +2.8 \\
\hline \multirow[t]{2}{*}{$2050 * *$} & +14.3 & +22.5 \\
\hline & \multicolumn{2}{|c|}{ Slovakia } \\
\hline 2004 & - & - \\
\hline 2010 & +2.9 & +3.6 \\
\hline 2017 & +2.6 & +2.0 \\
\hline $2020 * *$ & +1.6 & -9.4 \\
\hline $2050 * *$ & +13.9 & +24 \\
\hline
\end{tabular}

*prognostic data

Source: as in table 2

Using WSD index, it is possible to assess the rate of population ageing. If the values of WSD are positive, it means a faster process of population ageing. In contrast, negative values of WSD index indicate that populations become younger. The analysis of WSD index shows that in Poland and Slovakia WSD index has positive values over the whole analysis period (2004-2050), which means an increasing population ageing. In Poland this process is more dynamic, as indicated by higher values of WSD index. The difference between WSD values for Poland and Slovakia may be due to changes in the shares of the sub-populations of children and older people over time, which may vary in these countries. From the perspective of the labour market, it is important to assess the 
population ageing in economic terms. WSE index is based on the assumption that an increase in the share of pre-working and mobile working age population leads to population getting younger, whereas an increase in the share of non-mobile working and post-working age population leads to population getting older. Therefore, its values can range from -200 to +200 (Kurek, 2008). As with the previous index, positive values mean that this sub-population is getting older, whereas negative ones indicates that it is getting younger. In Poland, over the whole analysis period WSE values were positive, i.e. from +6 to +22.5 . Against a similar trend as in Poland, Slovakia recorded negative values of WSE between 2017 and 2020. This means that the ageing process of the working age group is much milder. Among the causes of this phenomenon are a decrease in the number of births and the intensity and directions of migrations, especially external ones. Thus, the dynamics of the population ageing process, taking into account various parameters of population age structure, showed variety of the phenomenon addressed in this paper. Moreover, it can be seen that the ageing process is more dynamic in working age population, which is very significant from the perspective of the labour market. There is no doubt that employers are increasingly facing the problem of staff recruitment, which will require a new perspective on the process of human resource management (Gorzeń-Mitka, 2018, Sitek, 2017, Skibiński, et al., 2016). Currently, various actions are taken to minimise the consequences of the inevitable process of labour force ageing. In order to develop an effective strategy for human resources management, it seems important to find out the opinions and views of professionally active people employed mainly in the SME sector. In view of the above, the respondents were asked whether they notice the problem of ageing labour fore at workplace. The responses of the research population are presented in figure 1.

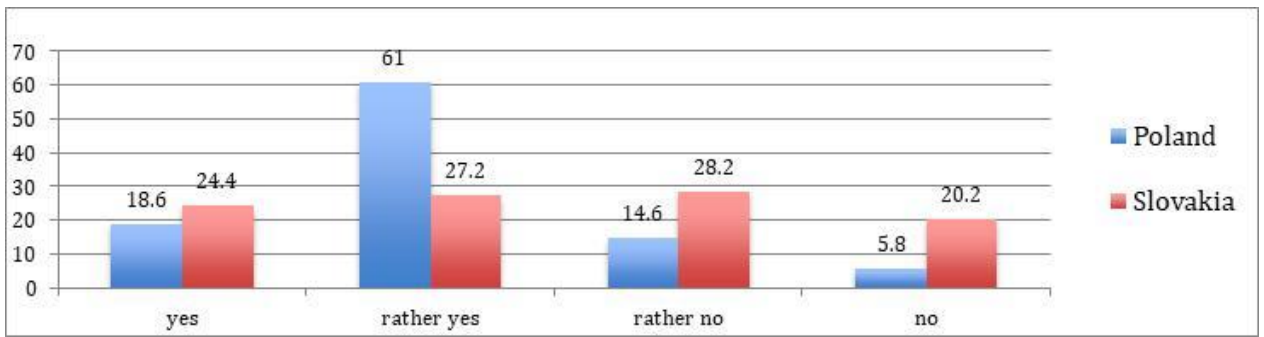

Fig. 1. Distribution of the respondents' responses on the subject of perception of the problem of ageing labour force at workplace.

Source: own work based on survey

Data from Fig. 1 suggests that Polish respondents are more aware of the consequences of unfavourable demographic trends in labour force ageing than their Slovak counterparts. This can be seen from the survey results, where the percentage of the respondents who do not notice this problem is significantly lower for Poland. In this context, employers are expected to increasingly employ those in older age groups. For them, unit labour costs, i.e. nominal employment costs to productivity, are the key factor when deciding about employing and keeping such an employee. Therefore, the unwillingness to employ older people as observed on the demand side of the labour 
market is strongly affected by the perceived link between averagely growing pay and generally assumed decreasing productivity of this sub-population, connected with an increased risk of diseases, and consequently more frequent absence from work, among other things. It can be thus concluded that especially in Central Eastern European countries, older workers are perceived as less productive. Therefore, the respondents were asked: Which adopted solutions may discourage employers from employing people aged $50+$ ? The distribution of the responses is presented in Table 5.

Table 5. The research population's opinions about the solutions discouraging employers from employing people aged $50+$.

\begin{tabular}{|l|c|c|c|c|}
\hline \multirow{2}{*}{ type } & \multicolumn{2}{|c|}{ Poland } & \multicolumn{2}{c|}{ Slovakia } \\
\cline { 2 - 5 } & $\begin{array}{c}\text { ranking of } \\
\text { indicator }\end{array}$ & $\%$ & $\begin{array}{c}\text { ranking of } \\
\text { indicator }\end{array}$ & $\%$ \\
\hline protection of pre-retirement people & 3 & 21.0 & 3 & 17.3 \\
\hline high taxes & 6 & 5.4 & 7 & 5.2 \\
\hline lack of tax exemptions & 7 & 4.8 & 5 & 8.6 \\
\hline younger employees are less expensive than older ones & 1 & 23.1 & 2 & 22.2 \\
\hline abuse of the rights of older employees & 4 & 15.1 & 6 & 5.6 \\
\hline high employment costs & 5 & 8.5 & 4 & 9.9 \\
\hline high absence from work due to illness & 2 & 22.1 & 1 & 31.2 \\
\hline
\end{tabular}

Source: as in fig. 1

The distribution of the respondents' responses in Table 5 shows that respondents in Poland and Slovakia most often indicated employment costs (the younger are less expensive) and high absence from work due to illness. They were followed by protection of pre-retirement people. From the third position, respondents' responses differed due to their country of origin. It can thus be concluded that employers' concerns about employing people in older age groups may be connected with the fact that in the event of a deteriorating financial situation companies will be unable to dismiss such employees. That's why they prefer employing younger people, who are not covered by preretirement protection and are less expensive, as they have lower pay requirements (Kryńska, 2013; Kryńska and Kopycińska, 2015; Broniatowska, 2016, ). The discussion presented so far clearly shows the shrinking of potential labour force, and there is nothing to indicate that this trend could be reversed in the next years. Part of the solution to this problem is for the government to take such actions that could slow down or reduce the consequences of the shrinking of working age population. One of them is to promote professional activity among older people and financial assistance to employers. Below are respondents' opinions about system solutions to encourage employers to employ people aged $50+$ (Tab. 6).

Table 6. Distribution of respondents' opinions about system solutions facilitating employment of people aged $50+$.

\begin{tabular}{|l|c|c|c|c|}
\hline \multirow{2}{*}{ type } & \multicolumn{2}{|c|}{ Poland } & \multicolumn{2}{c|}{ Slovakia } \\
\cline { 2 - 5 } & $\begin{array}{c}\text { ranking of } \\
\text { indicator }\end{array}$ & $\%$ & $\begin{array}{c}\text { ranking of } \\
\text { indicator }\end{array}$ & $\%$ \\
\hline $\begin{array}{l}\text { Flexible regulations with regard to labour code, such as } \\
\text { working time }\end{array}$ & 3 & 16.2 & 3 & 25.5 \\
\hline
\end{tabular}




\begin{tabular}{|l|c|c|c|c|}
\hline \multirow{2}{*}{ type } & \multicolumn{2}{|c|}{ Poland } & \multicolumn{2}{c|}{ Slovakia } \\
\cline { 2 - 5 } & $\begin{array}{c}\text { ranking of } \\
\text { indicator }\end{array}$ & $\%$ & $\begin{array}{c}\text { ranking of } \\
\text { indicator }\end{array}$ & $\%$ \\
\hline $\begin{array}{l}\text { Co-financing of training courses for people aged 50+ and } \\
\text { assistance in increasing their participation in the labour } \\
\text { market }\end{array}$ & 1 & 33.3 & 1 & 31.6 \\
\hline Tax exemptions & 2 & 29.9 & 2 & 25.6 \\
\hline $\begin{array}{l}\text { Limitation (amendment) of the provision concerning the } \\
\text { prohibition of dismissal of a pre-retirement employee }\end{array}$ & 4 & 16.0 & 4 & 17.3 \\
\hline Other & 5 & 4.6 & 5 & 0.0 \\
\hline
\end{tabular}

Source: as in fig. 1

The respondents' opinions presented in Table 6 show that the respondents most often indicated forms of financial support from the government such as: co-financing of training courses for people aged 50+ and tax exemptions. They were followed by flexible regulations with regard to the labour code and relaxation of the provisions that protect pre-retirement employees from dismissal. In this case, respondents in Poland and Slovakia agreed in their opinions about system solutions in this matter.

\section{Conclusion}

Population ageing is connected with numerous factors and consequences, which requires looking at this process in a multifaceted and interdisciplinary way. This is particularly visible in the context of social, medical and economic sciences. The numerous consequences of population ageing include old age dependency. Research has shown that the ageing of population, especially that of working age population, will be more rapid in Poland than in Slovakia. This is confirmed by demographic and economic ageing indexes. Moreover, results of the questionnaire survey show that there is still discrimination on the grounds of age. According to the respondents, employers are unwilling to employ people aged $50+$ because of the pre-retirement protection, high absence from work due to illness and high employment costs. A solution that could mitigate the effects of labour force ageing, according to the respondents, is government's actions to increase co-financing of training courses and assistance in increasing the participation of people aged $50+$ in the labour market. In ageing populations, it is very important to shape appropriate attitudes of young people towards the older in order to deepen the intergenerational integration in the society and organisations. Combining the potential of young people at the start of their professional careers and that of employees aged 50+ provides a chance to implement transfer of knowledge, and thus for an enterprise to achieve benefits. Summing up, the main challenge of the future in the face of ageing is to guarantee development of human capital, because societies will be older, but they will be also better educated and healthier. This will make it possible to not only decompensate the quantitative loss of labour force by their qualitative development, but also to cope with the burdens resulting from the increased number of older people. 


\section{References}

Bijak, J., Courgeau, D., Silverman, E.,Franck, R. (2014). Quantifying paradigm change in demography. Demographic Research, 30(1), pp. 911-924.

Broniatowska, P. (2017). Population Ageing and Inflation. Population Ageing, pp.1-15.

Caldwell, J. C. (2006). Population Intensification Theory. In Demographic Transition Theory, pp. 71-87.

Długosz Z., (1998). Próba określenia zmian starości demograficznej Polski w ujęciu Przestrzennym. Wiadomości Statystyczne nr 3, GUS-PTS, Warszawa, pp. 15-25.

Frątczak, E. Z. (2016). The Demographic Crisis and Global Migration-Selected Issues. Papers on Global Change IGBP, 23(1), pp. 71-87.

Golinowska S., (2008). Społeczno-ekonomiczne konsekwencje starz̨enia sie ludności. [in]: Konsekwencje ekonomiczne i społeczne starzenia się społeczeństwa. Klees J. (ed.). PAN, Komitet Prognoz Polska 2000 Plus, Warszawa, pp. 27-46.

Gorzeń-Mitka I. (2018). Leading markers of risk culture in organization. European Journal of Sustainable Development, 7(1), pp. 425-434.

Lee R.D., Reher D.S., (2011). Demographic transition and its consequences. Population and development review. 37. pp. 11-33

Kirk, D. (2016). Demographic Transition Theory. Population Studies, 50(3), pp. 361-387.

Kowaleski J.T., Szukalski P., (2008). Pomyślne starzenie się w perspektywie nauk o pracy i polityce społecznej. Komitet Nauk Demograficznych PAN, PTG, Zakład Demografii i Gerontoligii Społecznej Ut, Lódź.

Kryńska, E., Kopycińska, D. (2015). Wages in Labour Market Theories. Folia Oeconomica Stetinensia, 15(2), pp. 177-190.

Kryńska E. (ed.), (2013). Elastyczne formy zatrudnienia i organizacii pracy a aktywność zawodowa osob starssych. Instytut Pracy i Spraw Socjalnych, Warszawa, pp. 219-254

Kurek S., (2008). Typologia starzenia się ludności Polski w ujęciu przestrrzennym. Wydawnictwo Naukowe Akademii Pedagogicznej, Kraków, pp. 76-77.

Matthews, S. A., Parker, D. M. (2013). Progress in spatial demography. Demographic Research, 28, pp. 271312.

McDonald, P. (2013). Societal foundations for explaining low fertility: Gender equity. Demographic Research, 28, pp. 981-994.

Sitek M., (2017). Innovative forms of investments and modern concepts of management of resources in the real estate market, Entrepreneurship and Management, Volume XVIII, 1(1), pp. 285-299.

Skibiński A. (2017). The Changes of the Population Structure and its Consequences in Selected EU Countries - Some Aspects. European Journal of Sustainable Development. 6(1), pp. 357-368.

Skibiński, A., Sipa, M., Gorzeń-Mitka, I. (2016). An Intergenerational Cooperation in the Organization View from the Age Perspective. Procedia - Social and Behavioral Sciences, 235, pp. 412-419.

Sobotka, T. (2008). Overview chapter 6: The diverse faces of the second demographic transition in Europe. Demographic Research

Van De Kaa, D. J. (1987). Europe's second demographic transition. Population Bulletin, 42(1), pp.1-59. 